\title{
Ammonia recovery from human urine as liquid fertilizers in hollow fiber membrane contactor: Effects of permeate chemistry
}

\author{
Mekdimu Mezemir Damtie ${ }^{1}$, Federico Volpin ${ }^{3}$, Minwei Yao ${ }^{3}$, Leonard Demegilio Tijing ${ }^{3}$, \\ Ruth Habte Hailemariam ${ }^{1}$, Teng Bao ${ }^{3}$, Kwang-Duck Park ${ }^{2}$, Ho Kyong Shon ${ }^{3}$ June-Seok Choi ${ }^{{ }^{1,2}{ }^{+}}$ \\ ${ }^{1}$ Department of Construction Environment Engineering, KICT School, University of Science \& Technology, 217, Gajeong-ro, Yuseong-gu, Daejeon, \\ 34113, Republic of Korea \\ ${ }^{2}$ Department of Land, Water and Environment Research, Korea Institute of Civil Engineering and Building Technology, 283, Goyang-Daero, \\ Ilsanseo-Gu, Goyang-Si, Gyeonggi-Do,10223, Republic of Korea \\ ${ }^{3}$ Centre for Technology in Water and Wastewater, School of Civil and Environmental Engineering, University of Technology, Sydney (UTS), P.O. Box \\ 123, Broadway, NSW 2007, Australia
}

\begin{abstract}
The production of the existing nitrogen fertilizer is costly and less environmental-friendly. Various green technologies are currently emerging toward providing alternative options. In this study, a liquid/liquid hydrophobic hollow-fiber membrane contactor was employed at ambient temperature and natural urine $\mathrm{pH} \sim 9.7$ to recover ammonium fertilizers from human urine. Results showed that permeate side chemistry was one of the major factors affecting the ammonia mass transfer. The study on the ammonia capturing performance of diluted sulfuric acid, phosphoric acid, nitric acid, and DI water confirmed that acid type, acid concentration, and permeate side operating $\mathrm{pH}$ were the most important parameters affecting the ammonia capturing tendency. Sulfuric acid was slightly better in capturing more ammonia than other acid types. The study also identified increasing acid concentration didn't necessarily increase ammonia mining tendency because there was always one optimum concentration value at which maximum ammonia extraction was possible. The best permeate side operating $\mathrm{pH}$ to extract ammonia for fertilizer purposes was selected based on the dissociation equilibrium of different types of acids. Accordingly, the analysis showed that the membrane process has to be operated at $\mathrm{pH}>3$ for sulfuric acid, between 3.5 to 11.5 for phosphoric acid, and above 0.5 for nitric acid so as to produce their respective high-quality liquid ammonium sulfate, ammonium monophosphate/diphosphate, and ammonium nitrate fertilizer. Therefore, permeate side acid concentration, $\mathrm{pH}$, and acid type has to always be critically optimized before starting the ammonia mining experiment.
\end{abstract}

Keywords: Ammonia recovery, Fertilizer production, Human urine, Hollow-fiber membrane contactor

\section{Introduction}

Plants obtain their nutrients from fertilizer supply. Nitrogen is relatively one of the macro-elements required in the biggest amount [1]. This nitrogen can only be taken in the form of ammonium and nitrate which is can be found easily from the commercial fertilizer. The production of the existing nitrogen fertilizer was based on the Haber-Bosch process which is a costly process of manufacturing ammonia by mixing nitrogen and hydrogen from the air using a catalyst. It is less environmental-friendly and consumes a considerable amount of global energy [2].
Nitrogen recovery from various waste sources can be an alternative option to assist or fully substitute the prevailing system. Urine is one of the most nitrogen-rich wastes that potentially provide a high nitrogen source. Moreover, mining nitrogen before it joins the treatment plant entails additional benefit in reducing the cost which otherwise would be incurred in nitrogen and phosphorus removal in advanced tertiary level treatment system [3].

Various green technologies are currently emerging toward providing alternative options to supply nitrogen. [4] utilized a hybrid process involving biological processes with distillation technology. In this method, a membrane-aerated biofilm reactor was operated to produce a nutrient solution having high ammonium nitrate com-
This is an Open Access article distributed under the terms of the Creative Commons Attribution Non-Commercial License (http://creativecommons.org/licenses/by-nc/3.0/) which permits unrestricted non-commercial use, distribution, and reproduction in any medium, provided the original work is properly cited.
Received December 27, 2019 Accepted January 13, 2020

${ }^{\dagger}$ Corresponding author

Email: jschoi@kict.re.kr

Tel: +82-31-910-0759 Fax: +82-31-910-0291 
position which later concentrated and recovered as a dry powder using the conventional distillation process. This technology is interesting but consumes high energy in the distillation process. Moreover, recovering valuable resources from urine in the feed side also has the risk of absorbing pharmaceuticals and other micropollutants of the urine in the final product. Another similar study $[5,6]$ also considered the hybrid of ureolysis and precipitation technology toward precipitating minerals such as struvite and octacalcium phosphate. However, this technology also has some disadvantages such as having a slow biological process and the tendency of having poor quality fertilizer. There are also studies which recovered minerals from various nitrogen-rich sources in the conventional stripping process [7-10]. This technology basically looks simple and has been extensively studied for ammonia nitrogen recovery by different scientists. However, its biggest disadvantage goes to the investment incurred on the continuous heating and aeration requirements. There is also a study [11] using a reverse osmosis membrane to recover nitrogen through concentrating the feed and increasing the osmotic pressure. This process requires high energy for putting the hydraulic pressure in place and special membranes with high mechanical strength. [12, 13] also investigated ion exchange for recovery of nitrogen as ammonium from urine for use as a fertilizer and disinfectant. In this process urea gets hydrolyzed naturally and forms ammonium $\left(\mathrm{NH}_{4}^{+}\right)$then materials with negatively charged sites will be utilized to adsorb the ammonium. The major limitation of this process is the preparation of such negatively charged material adsorbing ammonium is not easy, complete recovery of ammonium is not possible, and a high dose of adsorbent is required in case of using high-nitrogen feed sources such as human urine.

In this study, therefore, a liquid/liquid hydrophobic hollow-fiber membrane contactor (HFMC) was employed to recover ammonium fertilizers from human urine. This technology allows direct contact and easy mass transfer between gaseous and liquid phases. In HFMC there is a high tendency of recovering any kind of volatile resources such as ammonia. This method generally requires less energy [14] and there is also a high tendency of being harmonized with green energy as less temperature and no aerations were required. Moreover, this technology is environmentally friendly, less chemical-intensive., much faster than normal stripping as it provides a large active surface area between the feed urine and stripping acid solutions [3]. It also has the highest packing density. This technology has been employed in the direct contact membrane distillation process for arsenic [15], heavy metal [16], fluoride [17-20], desalination [21].

There are a couple of studies who applied the hollow fiber direct contact membrane distillation process to recover nitrogen as a fertilizer [3, 14, 22]. Quite a considerable amount of study has been released so far regarding the effect of some of the most important parameters on the ammonia recovery performance of the hollow-fiber contactor. Generally, studies show that various parameter affects ammonia capturing performance of the membrane contactors. These factors can be summarized into three categories: feedwater behavior, module/membrane type, and the operating parameters [23].

However, among all these parameters, the effect of permeate chemistry was given less attention as it seems to be less significant. Some studies such as [23-25] slightly addressed the permeate chemistry issue but still lack to clearly indicate the rationale how it affects the ammonia capturing tendency. The permeate chemistry also has an indirect effect on the ammonium capturing tendency of the permeate which has not been addressed so far by any of the studies conducted in the HFMC. This study, therefore, strongly focuses on addressing issues pertinent to the dominant chemical behaviors of the permeate side and how they are linked to the ammonia diffusion rate. The study mainly includes the type of acid, effect of permeate $\mathrm{pH}$, and acid concentration.

\section{Material and Methods}

\subsection{Membrane Module and Devices}

Commercially available hydrophobic polyvinylidene fluoride (PVDF) membrane was provided by Econity, Korea. The membrane was applied to a hollow fiber liquid/liquid type bench-scale direct contact membrane distillation contactors. A cell has an effective membrane area of $0.0033 \mathrm{~m}^{2}$. The HF membranes had inside and outside diameters of $0.77 \mathrm{~mm}$ and $1.30 \mathrm{~mm}$, respectively. The mean pore size, porosity, and liquid entry pressure of the membranes were $0.1 \mu \mathrm{m}, 63 \%$, and $2.3 \mathrm{bar}$, respectively. The chemical equilibrium diagrams and speciation for various solutions were analyzed using Medusa-Hydra developed by (KTH, Sweden).

A peristaltic pump was used for the feed side (Watson Marlow peristaltic pump 323S/D, United Kingdom). In the permeate side also a low flow rate peristaltic pump was used (BT 100-2J, Thermoline Scientific, Australia). Other devices include a heater (TU1 UNISTAT heater circulator, Thermoline scientific, Australia), chiller (Refrigerated Bath Circulator, CPT Inc., Republic of Korea). Temperature, $\mathrm{pH}$ meter, and conductivity meter (HQ40d Portable Multi-Parameter meter, Hach Company, Australia), and a digital pressure sensor for measuring the liquid entry pressure (10.00 bar, Autonics PSA-1, USA).

\subsection{Urine Feed Composition and Chemicals Utilized}

A simulated hydrolyzed human urine modified from the composition of a recent study [26] was adopted (Table 1). The chemicals utilized in the synthesis were $\mathrm{NaOH}, \mathrm{H}_{2} \mathrm{SO}_{4}, \mathrm{H}_{3} \mathrm{PO}_{4}$, $\mathrm{HNO}_{3}, \mathrm{NH}_{4} \mathrm{Cl}, \mathrm{Na}_{2} \mathrm{SO}_{4},\left(\mathrm{NH}_{4}\right)_{2} \mathrm{CO}_{3}$, and $\mathrm{Na}_{3} \mathrm{C}_{6} \mathrm{H}_{5} \mathrm{O}_{7} .2 \mathrm{H}_{2} \mathrm{O}$ (Aldrich, Switzerland), $\mathrm{Na}_{3} \mathrm{C}_{6} \mathrm{H}_{5} \mathrm{O}_{7} .2 \mathrm{H}_{2} \mathrm{O}$ (Aldrich, Canada), $\mathrm{KH}_{2} \mathrm{PO}_{4}$, and $\mathrm{KCl}$

Table 1. Chemical Composition of Hydrolyzed Stale Urine $(\mathrm{g} / \mathrm{L})$

\begin{tabular}{lc}
\hline Chemicals & SU \\
\hline$\left(\mathrm{NH}_{4}\right)_{2} \mathrm{CO}_{3}$ & 40.07 \\
$\mathrm{NaCl}$ & 4.60 \\
$\mathrm{KCl}$ & 1.60 \\
$\mathrm{KH}_{2} \mathrm{PO}_{4}$ & 2.79 \\
$\mathrm{NH}_{4} \mathrm{Cl}$ & 1.00 \\
$\mathrm{Na}_{2} \mathrm{SO}_{4}$ & 2.30 \\
$\mathrm{C}_{4} \mathrm{H}_{7} \mathrm{~N}_{3} \mathrm{O}$ & 1.10 \\
$\mathrm{CaCl}_{2} \cdot 2 \mathrm{H}_{2} \mathrm{O}$ & 0.65 \\
$\mathrm{MgCl}_{2} \cdot 6 \mathrm{H}_{2} \mathrm{O}$ & 0.65 \\
$\mathrm{Na}_{3} \mathrm{C}_{6} \mathrm{H}_{5} \mathrm{O}_{7} \cdot 2 \mathrm{H}_{2} \mathrm{O}$ & 0.65 \\
$\mathrm{Na}_{2} \mathrm{C}_{2} \mathrm{O}_{4}$ & 0.02 \\
\hline
\end{tabular}


(Chem-supply, Australia), $\mathrm{CaCl}_{2} \cdot 2 \mathrm{H}_{2} \mathrm{O}$ and $\mathrm{NaCl}$ (BDH Chemicals, United Kingdom), $\mathrm{MgCl}_{2} \cdot 6 \mathrm{H}_{2} \mathrm{O}$ (March KGaa EMD Millipore, Germany), $\mathrm{C}_{4} \mathrm{H}_{7} \mathrm{~N}_{3} \mathrm{O}$ (Glentham life sciences chemicals, United Kingdom).

\subsection{Nitrogen Recovery Experiment}

The feed and permeate volume were $500 \mathrm{ml}$ and the permeate acidity was varying from $0.005 \mathrm{M}$ to $0.6 \mathrm{M}$. The experiment was conducted for about $200 \mathrm{~min}$ and the feed flow rate and permeate flow rate were constantly kept to be $200 \mathrm{~mL} / \mathrm{min}$ and $100 \mathrm{~mL} / \mathrm{min}$, respectively. An ambient temperature and natural urine $\mathrm{pH} \sim 9.7$ were kept throughout the experiment. As per the recommendation from [23], the synthetic urine with a chemical composition in Table 1 was circulated on the shell side and the diluted acid flowed counter-currently on the lumen side of the membrane with an objective of moving the ammonia ion through the hydrophobic membrane with the driving force being the chemical reaction of the acid with ammonia gas. Details of the process were shown in the schematics below see Fig. 1. Temperature, conductivity, and $\mathrm{pH}$ of both the permeate and feed sides were continuously measured throughout the experiment. Every $30 \mathrm{~min} 10 \mathrm{~mL}$ of samples were taken from the permeate to measure the ammonium-Nitrogen concentration.

$\mathrm{NH}_{3}+\mathrm{H}_{2} \mathrm{O} \rightarrow \mathrm{NH}_{4}+\mathrm{OH}^{-} \rightarrow \mathrm{NH}_{4}+\mathrm{H}_{2} \mathrm{SO}_{4} \rightarrow\left(\mathrm{NH}_{4}\right)_{2} \mathrm{SO}_{4}(1)$

\section{Results and Discussions}

Various behaviors of permeate chemistry can affect the ammonia gas abstraction tendency among which our study identified the type of acid and its level of concentration are the most influential parameters. The overall response of the HFMC system has been evaluated from the point of view of the rate of change of permeate $\mathrm{pH}$, ammonia uptake amount, change in the permeate conductivity and permeate temperature change. The results were described as follows.

\subsection{Effect of Acid Type}

Generally, in ammonia stripping, any solution can be utilized in the permeate side. However, it should be noted that the Knudsen diffusion of ammonia gas first takes place through the HFMC, reacts with the permeate solution, and then forms different types of compounds [23]. For instance, it stays as ammonium hydroxide in water-based permeate solutions and as an ammonium sulfate salt in a sulfuric acid-based permeate solutions. The type of receiving solutions to be used merely depends on the purpose for which the final ammonium-based product is to be utilized. In this study, ammonia gas is extracted with a target of producing ammonium salts that can be utilized as a fertilizer in the agriculture industry. In fertilizer production, any acidic solutions can be used for stripping as long as it is capable enough to reduce the permeate $\mathrm{pH}$ below the ammonium and ammonia dissociation equilibrium point ( $\mathrm{Pk}$ $=9.24)$. Where, $\mathrm{Pk}=$ the logarithm of the reciprocal of the acid dissociation constant (Ka) (see Fig. 3(d) and Eq. (1) ) because ammonia cannot stay as $\mathrm{NH}_{3}$ gas in the basic $\mathrm{pH}$ range and all the ammonia gas tends to change to ammonium and forms different kinds of ammonium salts [27]. There are different possibilities to find out low $\mathrm{pH}$ solutions among which blending the diluted commercial pure acid with the basic acid and buffer can be one. This option is often the cheapest option for creating a low $\mathrm{pH}$ permeate solution. The other advantage is the rate of change of $\mathrm{pH}$ to neutral state is very slow due to the buffer properties so that a lot of ammonia can be captured by adjusting and keeping its buffer property. In blending and buffering with predetermined salts, there can also be a possibility of adding useful primary and secondary elements important for production of fertilizers.
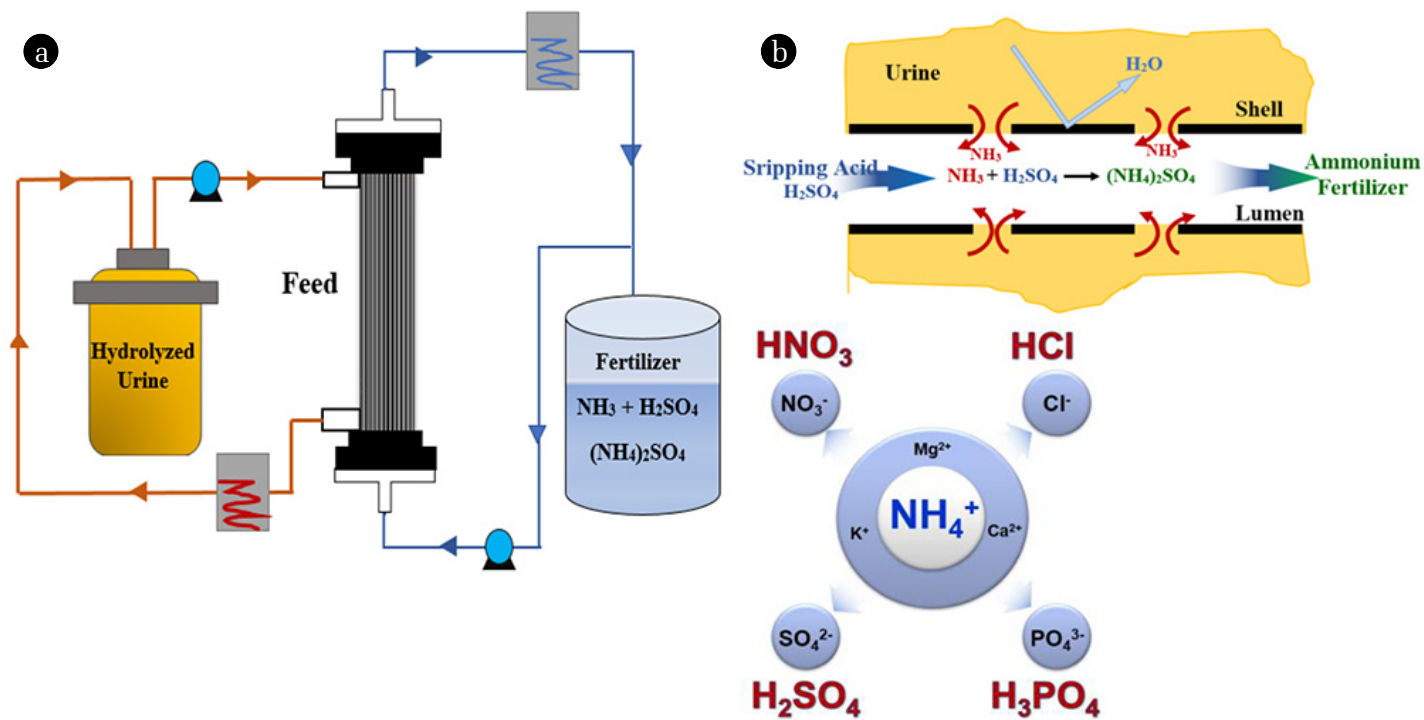

Fig. 1. Schematic of application of HFMC system for ammonium fertilizer production. (a) General schematics of the HFMC process. (b) lons which are sources of the primary and secondary elements required for plant growth. 

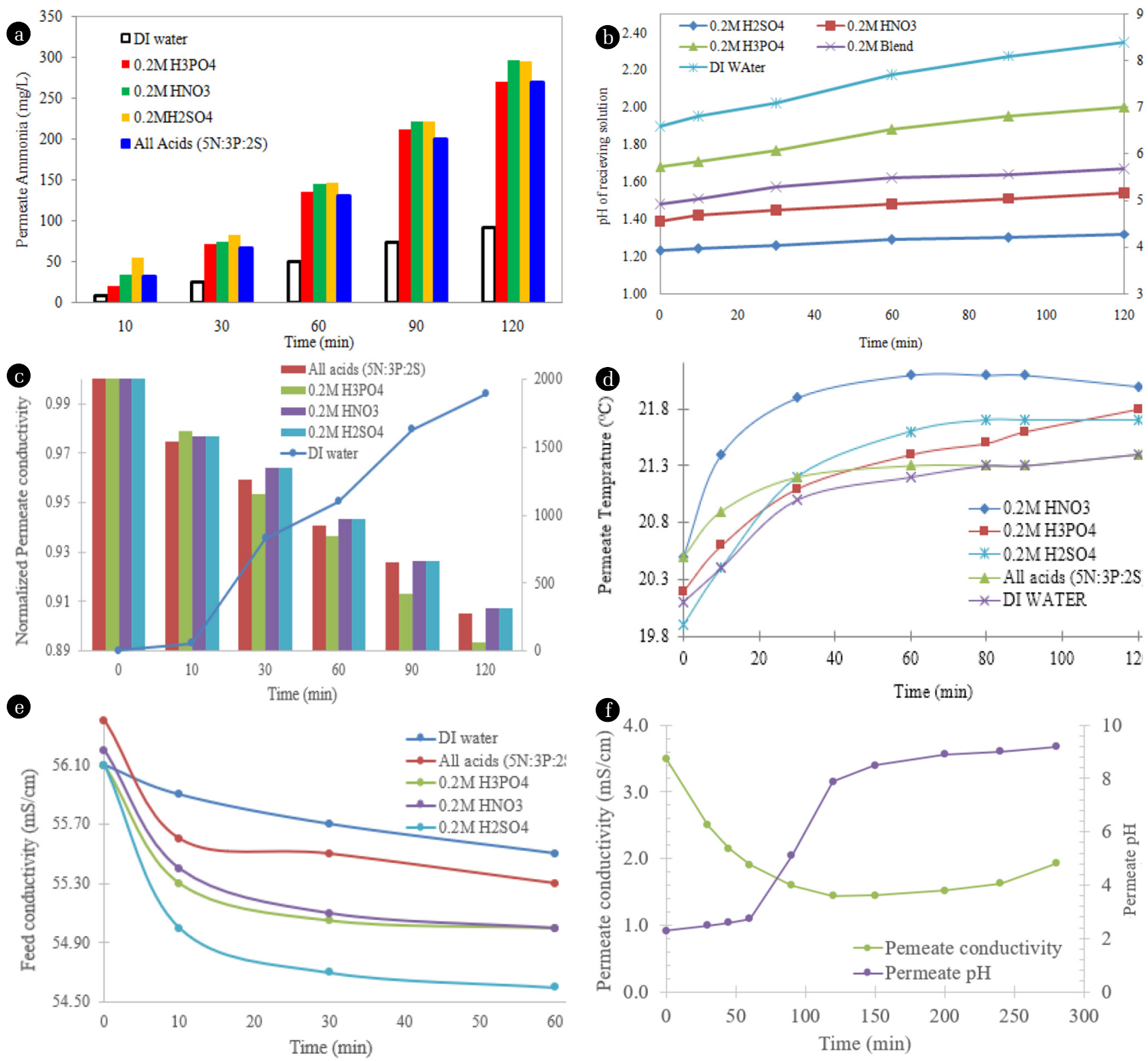

Fig. 2. Response of the receiving solution from utilizing different type of acids: (a) Ammonia-nitrogen uptake performance of a different type of receiving solutions; (b) pH response of receiving permeate solution; (c) Conductivity response of the permeate; (d) temperature response of the permeate; (e) Feed conductivity response; (f) Conductivity and $\mathrm{pH}$ response of $0.005 \mathrm{M} \mathrm{H}_{2} \mathrm{SO}_{4}$. Experimental Condition: ${ }^{*} F / P$ temperature $=21 / 21^{\circ} \mathrm{C} ; \mathrm{F} / \mathrm{P}$ flow rate $=200 / 100 \mathrm{~mL} / \mathrm{min} ; \mathrm{F} / \mathrm{P}$ volume $=500 / 500 \mathrm{~mL}$; Feed $\mathrm{pH}=8.9$. ${ }^{*} \mathrm{~F} / \mathrm{P}$ stands for feed/ permeates; $5 \mathrm{~N}: 3 \mathrm{P}: 2 \mathrm{~S}$ stands for a blend of three acids (nitric, phosphoric, and sulfuric) in 5:3:2 ratios respectively. IC = Initial permeate conductivity (mS/ $\mathrm{cm}$ )). Remark: this experiment was conducted three times and arithmetic averages were taken. Ammonia capturing performance and fertilizer formation

In this study, only five different low $\mathrm{pH}$ solutions were considered to study the ammonia extraction performance of HFMC from human urine (i.e. DI water, phosphoric, sulfuric, nitric, and blend of all acids). The blend acid contains nitric, phosphoric, and sulfuric acid in 5:3:2 ratio. These inorganic acids were selected because they basically have the most important primary or secondary anion sources for the growth of plants that can be obtained from fertilizers (primary elements required for plant growth are $\mathrm{N}, \mathrm{P}, \mathrm{K}$ and secon- dary are S, Ca, Mg see Fig. 1(b)) [1]. The response of these acids in the experiment has been evaluated based on their effect on changing the receiving solution behavior. These response includes the ammonia-nitrogen capturing performance (Fig. 2(a)), pH increment of permeate solution (Fig. 2(b)), permeate conductivity response (Fig. 2(c), (f)), temperature response (Fig. 2(d)), and feed conductivity response (Fig. 2(e)). The response of different types of acids and their respective relevance with fertilizer formation 
was discussed as follows.

\subsection{Ammonia Capturing Performance and Fertilizer Formation}

As shown in Fig. 2, the comparison of the five permeate solution revealed that sulfuric acid was relatively superior in its ammonia capturing tendency (see Fig. 2(a)) followed by nitric acid, blend of all acid, phosphoric acid, and DI water respectively. This is mainly due to the interaction between the ammonium and the anion from the permeate acid dissociation. As you can see in Fig. 2(b), at the end of the process, the final permeate solution $\mathrm{pH}$ of sulfuric acid was 1.3. At this $\mathrm{pH}$, there is a high tendency of formation of $\left(\mathrm{NH}_{4}\right)_{2} \mathrm{SO}_{4}$ even though there are still some possibilities that $\mathrm{NH}_{4} \mathrm{HSO}_{4}$ might also be formed. Therefore formation of $\left(\mathrm{NH}_{4}\right)_{2} \mathrm{SO}_{4}$ means, one molecule of $\mathrm{SO}_{4}{ }^{2-}$ captured two molecules of $\mathrm{NH}_{4}{ }^{+}$ion. This phenomenon ultimately enhances the ammonia capturing tendency and also affects the other permeate responses (see Eq. (2)). But for other acids, at such a small pH, only one $\mathrm{NH}_{4}$ molecule was being captured by their respective acid dissociates (see Eq. (2) to (8)) [24]. This also clearly shows that HFMC cannot be operated at any permeate $\mathrm{pH}$. Hence the issue remains at what final permeate $\mathrm{pH}$ value to end the experiment. There is an optimum $\mathrm{pH}$ range at which the HFMC system must be shutdown. This optimal $\mathrm{pH}$ range was selected based on the type of permeate solution to be extracted. In this experiment, only liquid fertilizer was targeted. Hence we selected the $\mathrm{pH}$ range at which there is a possibility of high-quality useful fertilizer production. Subsequently, for sulfuric acid as a permeate solution, the HFMC process shut down has to be set at any $\mathrm{pH}>3$ (see Eq. (2) and Fig. 3(a)) so as to produce high-quality liquid ammonium sulfate $\left(\mathrm{NH}_{4} \mathrm{HSO}_{4}\right)$ solution [23].

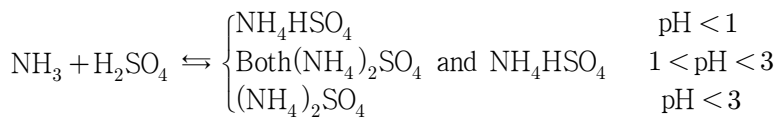

In a similar way, Eq. (3) showed different possible solutions being formed from using diluted phosphoric acid at different $\mathrm{pH}$. Monoammonium Phosphate (MAP), $\mathrm{NH}_{4} \mathrm{H}_{2} \mathrm{PO}_{4}$ and Diammonium phosphate (DAP) $\left(\mathrm{NH}_{4}\right)_{2} \mathrm{HPO}_{4}$ were the most important solutions that can be utilized as a fertilizer. Both are excellent fertilizers due to their rich phosphorus $(\mathrm{P})$ and nitrogen $(\mathrm{N})$ compositions. The HFMC operation can be set to any final $\mathrm{pH}$ value between 3.5 to 11.5 as both MAP and DAP can potentially be formed in this $\mathrm{pH}$ range. The only difference between these two fertilizers arises when the farmer has a special need on the soil $\mathrm{pH}$ or on the nitrogen and phosphorus amount.

$$
\mathrm{HN}_{3}+\mathrm{H}_{3} \mathrm{PO}_{4} \leftrightarrows\left\{\begin{array}{lc}
\mathrm{NH}_{4} \mathrm{H}_{2} \mathrm{PO}_{4} & 3.5<\mathrm{pH}<6 \\
\mathrm{NH}_{4} \mathrm{H}_{2} \mathrm{PO}_{4} \&\left(\mathrm{NH}_{\mathrm{r}}\right)_{2} \mathrm{HPO}_{4} & 6<\mathrm{pH}<8.5 \\
\left(\mathrm{NH}_{4}\right)_{2} \mathrm{HPO}_{4} & 8.5<\mathrm{pH}<11.5 \\
\left(\mathrm{NH}_{4}\right)_{2} \mathrm{HPO}_{4} \&\left(\mathrm{NH}_{4}\right)_{3} \mathrm{PO}_{4} & 11.5<\mathrm{pH}<14
\end{array}\right.
$$

The other possible nitrogen-rich fertilizer to be produced is from the diluted nitric acid solution. Ammonium Nitrate $\mathrm{NH}_{4} \mathrm{NO}_{3}$ has also an excellent role as a fertilizer. However, it can also be used as an explosive and an oxidizing agent. It can be formed at any operation $\mathrm{pH}$ above 0.5 (see Eq. (4)). This study also addressed the effect of utilizing a blend of all these three acids (N:P:S ratio of $5: 3: 2)$ in the same concentration $(0.2 \mathrm{M})$ as other acids. This solution generally exhibited an average behavior of its constituent acids and ended up with a mixed fertilizer having ammonium, nitrate, sulfate, monophosphate, and diphosphate compounds when it runs in the $\mathrm{pH}$ range between 3.5 and 11.5.

$$
\mathrm{NH}_{3}+\mathrm{HNO}_{3} \leftrightarrows \mathrm{NH}_{4} \mathrm{NO}_{3} \quad \mathrm{pH}>0.5
$$

The application of DI water as a permeate in the HFMC was not further considered for two major reasons. Primarily, it produced an ammonium hydroxide solution which is not applicable as fertilizer. Secondly, its ammonia capturing tendency was very slow and its $\mathrm{pH}$ responds very fast (see Fig. 2(b)). Once the $\mathrm{pH}$ reaches $\mathrm{pH}=9.2$ (see Eq. (4) and Fig. 3(d)) and ammonia concentration reaches saturation, there will be no more mass transfer through the hydrophobic membrane and even ammonia ion might start to migrate back to the feed side.

$$
\mathrm{NH}_{3}+\mathrm{H}_{2} \mathrm{O} \leftrightarrows \mathrm{NH}_{4} \mathrm{OH} \quad \mathrm{pH}>9.2
$$

Generally, from the above analysis, we can see that the final permeate has three very important behavior depending on the permeate acid strength and available ammonium ion.

a) Type $\mathbf{1}(\mathbf{p H}<\mathbf{6})$ : When the permeate is still in the acidic state and sufficient amount of ammonium has not been captured. This cannot generally be used as a fertilizer because of its acidity and less concentration of ammonium ion. The solution contains $\mathrm{H}_{2} \mathrm{SO}_{4}$ and $\left(\mathrm{NH}_{4}\right)_{2} \mathrm{SO}_{4}$ in a certain proportion.

b) Type $2(6<\mathbf{p H}<9)$ : When the permeate is in the neutral state owing to the presence of an equivalent amount of ammonium and sulfate ion. This kind of solution is perfect to be utilized as a fertilizer. As much as possible, the nitrogen recovery experiment has to always be stopped in this $\mathrm{pH}$ range so as to use for fertilizer purposes. The solution contains only $\left(\mathrm{NH}_{4}\right)_{2} \mathrm{SO}_{4}$.

c) Type 3 (pH > 9): When the permeate is in the alkaline state owing to the diffusion of an extra amount of ammonium ion. Even though there is no enough amount of sulfate ion, the ammonia transfer will continue and forms ammonium hydroxide. This solution also cannot be utilized as a fertilizer. The solution is basically composition of $\mathrm{NH}_{4}(\mathrm{OH})$ and $\left(\mathrm{NH}_{4}\right)_{2} \mathrm{SO}_{4}$ in a certain proportion.

\subsection{Permeate pH Response}

The percentage increase in permeate $\mathrm{pH}$ indicated in Fig. 2(b) was $7 \%, 11 \%, 13 \%, 19 \%$, and $72 \%$ for the sulfuric, nitric, blend, phosphoric acid, and DI water respectively. This mainly indicated that the $\mathrm{pH}$ of solutions with small ammonia capturing tendency responds so quickly. As ammonia is being received, the permeate $\mathrm{pH}$ tends to increase owing to the reduction of acidity and the formation of ammonium hydroxide solution [28]. This $\mathrm{pH}$ increase continues and might grow into a strong alkaline $\mathrm{pH}$. A typical example can be seen in Fig. 4(b) and Fig. 2(f). However, the ammonia mass transfer in the HFMC operation is strongly linked to its trans- 
membrane $\mathrm{pH}$ difference which is a powerful ammonia driving force. Hence it is advisable to keep the permeate $\mathrm{pH}$ as low as possible in order to receive more ammonia gas. This has been somehow confirmed elsewhere [29]

\subsection{Permeate Temperature Response}

As ammonia is being received, the temperature of the permeate solution was also observed to increase in different ways for different acids. This spontaneous temperature increase was higher for sulfuric acid which showed $1.7^{\circ} \mathrm{C}$ increase in $2 \mathrm{~h}$ followed by nitric acid which is $1.1^{\circ} \mathrm{C}$, and phosphoric acid $0.5^{\circ} \mathrm{C}$ see Fig. $2(\mathrm{~d})$. Moreover, this temperature increase was very fast and steep in nitric acid while it is gentle and slow in phosphoric acid. The temperature increase in the permeate solution was attributed to the exothermic reaction occurred between the ammonium ion and the acid dissociation anions. The highest temperature in the nitric acid was also mainly happening from the explosive behavior of the ammonium nitrate compound.

\subsection{Feed and Permeate Conductivity Response}

The other interesting response observed from the ammonia capturing was the feed and permeate conductivity decline. The feed side conductivity change was carefully measured and showed a substantial decline (from $\sim 56$ to $\sim 54 \mathrm{~ms} / \mathrm{cm}$ in $2 \mathrm{~h}$ see Fig. 2(e)). Sulfuric acid was relatively the most capable reducing the feed side conductivity and $\mathrm{pH}$ as the decline was mainly associated with the ammonia migration tendency. Moreover, as the ammonia abstraction increases, the conductivity of the permeate solution also significantly decreased (see Fig. 2(c) and (f)). This was mainly because the acidic permeate solution with high conductivity was slowly changing to $\mathrm{NH}_{4} \mathrm{SO}_{4}$ solution which has smaller conductivity than the previous acidic media. There are also cases at which the conductivity decrease initially and then tends to continuously increase thereafter (see Fig. 2(f)). This is mostly happening in very week acid solutions in which initially the $\mathrm{pH}$ decreases when the weak acid turns to dilute ammonium sulfate solution but later, with receiving more ammonia, the conductivity starts to significantly increase owing to the formation of alkaline ammonium hydroxide solution having high electrical conductivity. Generally, lower permeate conductivity is preferable for fertilizer production if we have to consider conductivity as one of the HFMC operating criteria. Usually, the permeate solution has to be diluted many times to be applied as a fertilizer for plant growth. The average conductivity of irrigation water should be less than $900 \mu \mathrm{s} / \mathrm{cm}$.
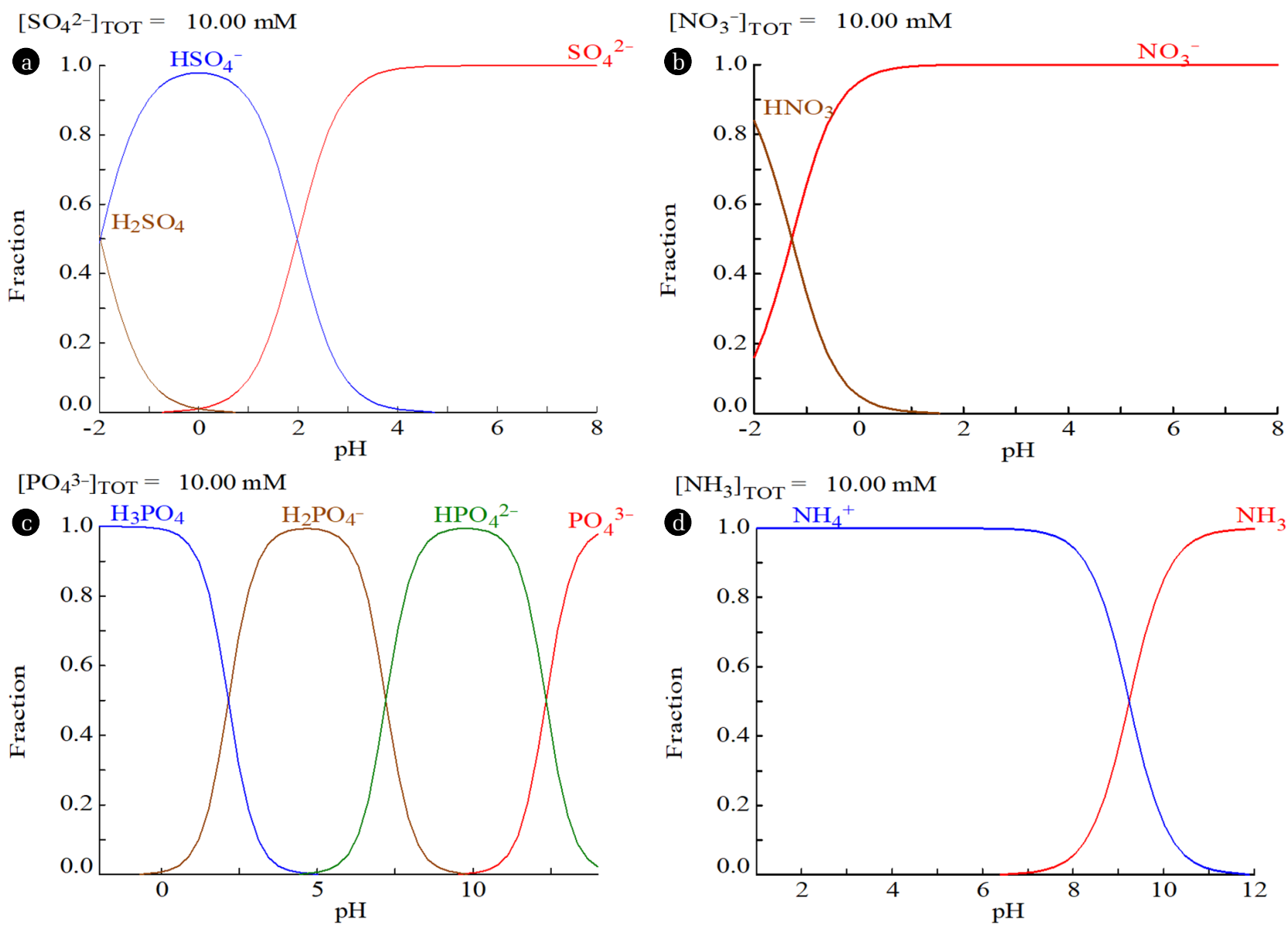

Fig. 3. Chemical equilibrium diagram for various ammonia receiving solutions in the HFMC permeate Side. (a) sulfuric acid; (b) Nitric acid; (c) Phosphoric acid; and (d) (f) Ammonium-ammonia dissociation equilibrium. 


\subsection{Effect of Permeate Acid Molar Concentration}

Fig. 4(a) to (d) shows the permeate conductivity and $\mathrm{pH}$ response of sulfuric and phosphoric acid. It generally showed that, as compared to sulphuric acid $(0.005 \mathrm{M})$, we require almost double times the concentration of phosphoric acid (e.g $0.01 \mathrm{M}$ ) to attain a similar level of ammonia capture, $\mathrm{pH}$, and conductivity response [24]. This is attributable to the formation of $\left(\mathrm{NH}_{4}\right)_{2} \mathrm{SO}_{4}$ solution in which one molecule of $\mathrm{SO}_{4}{ }^{2-}$ captured two molecules of $\mathrm{NH}_{4}{ }^{+}$ ion while only one $\mathrm{NH}_{4}^{+}$was being captured in phosphoric acid upon the formation of monophosphate compound (see Eq. (2) to (8)).

As can be seen in Fig. 4(e), the permeate ammonia uptake tendency didn't necessarily increase with the increasing permeate acid concentration of both sulphuric and phosphoric acid. Both highly diluted and highly concentrated permeate concentrations have reduced the ammonia capturing tendency of the permeate [23]. This is mainly because in weak acid the $\mathrm{pH}$ quickly increased and induced the transmembrane $\mathrm{pH}$ gradient reduction which ulti-
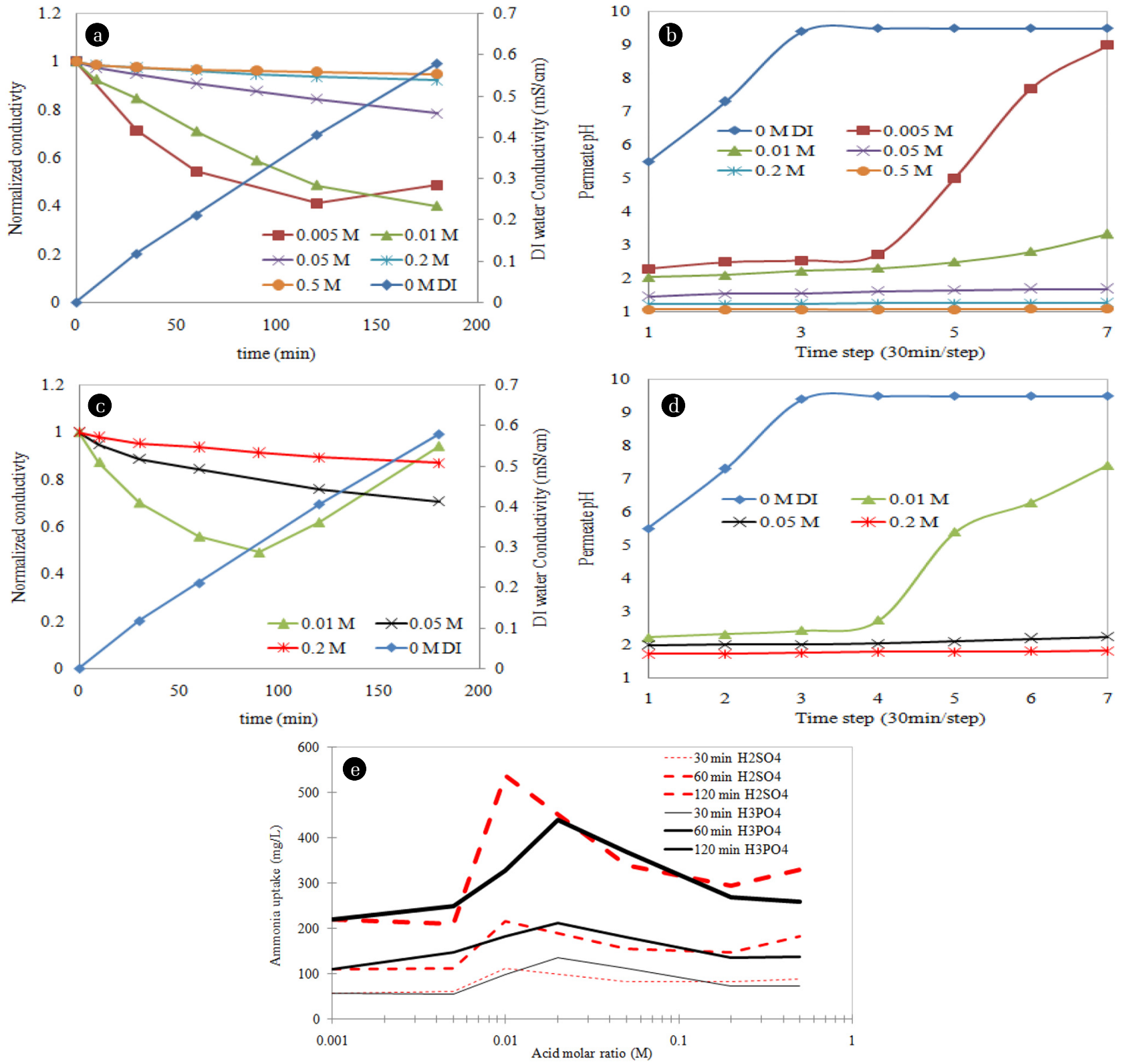

Fig. 4. Responses of the permeate receiving solution for different acid type and strength (a) Change in conductivity of $\mathrm{H}_{2} \mathrm{SO}_{4}$; (b) Change in pH of $\mathrm{H}_{2} \mathrm{SO}_{4}$ (c) Change in conductivity of $\mathrm{H}_{3} \mathrm{PO}_{4}$; (d) Change in $\mathrm{pH}$ of $\mathrm{H}_{3} \mathrm{PO}_{4}$ (e) Optimum ammonia uptake performance by different acid types. Experimental Condition: ${ }^{*} / \mathrm{P}$ temperature $=21 / 21^{\circ} \mathrm{C} ; \mathrm{F} / \mathrm{P}$ flow rate $=200 / 100 \mathrm{~mL} / \mathrm{min} ; \mathrm{F} / \mathrm{P}$ volume $=500 / 500 \mathrm{~mL} ; \mathrm{F} / \mathrm{P} \mathrm{pH}=8.9 / \mathrm{O} .2 \mathrm{M}$ acid and DI water. 
mately reduced the ammonia mass-transfer [24]. Whereas in the case of using a strong acid, permeate side viscosity and concentration polarization significantly increased thereby reducing the ammonia migration through the hydrophobic membrane [30]. Hence, we can deduce that for certain specific HFMC operating conditions, there is always an optimum permeate acid concentration at which the ammonia mass transfer rate hits its maximum value. For instance, for this specific operating condition shown in Fig. 4 (i.e no feed temperature and no feed $\mathrm{pH}$ increase), the optimum acid strength was $0.01 \mathrm{M}$ and $0.02 \mathrm{M}$ for $\mathrm{H}_{2} \mathrm{SO}_{4}$ and $\mathrm{H}_{3} \mathrm{PO}_{4}$ solutions respectively. A similar optimal value has been delivered elsewhere [30]. This acid concentration should be increased if we increase the feed $\mathrm{pH}$ and temperature because both $\mathrm{pH}$ and temperature increase the ammonia availability in the feed side.

\section{Conclusions}

The permeate chemistry in the DCMD process strongly affects the nitrogen recovery potential of the hydrophobic membrane. Any low $\mathrm{pH}$ acidic receiving solutions can be used as a permeate side solutions. However, their selection merely depends on the purpose for which the final ammonium-based product is to be utilized. The study on the ammonia capturing performance of diluted sulfuric acid, phosphoric acid, nitric acid, and DI water confirmed that acid concentration, and permeate side operating $\mathrm{pH}$ were the most important parameters. The $\mathrm{pH}$ determines the speciation equilibrium condition and should be carefully studied. Moreover, there is always an optimum acid concentration for certain specific HFMC operating conditions at which maximum ammonia can be harvested. Therefore permeate side acid concentration has to be optimized for every HFMC condition. The study also confirmed that the effect of the acid type was not significant. Even though different types of acids behave in a different manner as receiving-solution, the overall ammonia uptake efficiency was not really a big issue. We can use any diluted inorganic acid as long as the price and final application product solution was acceptable. The study of ammonia capturing performance and economic analysis of bending the acid with the basic acid and buffer properties can be a good future study topic.

\section{Acknowledgment}

This research was supported by an internal grant (code 20190278-001) from Korean government under the administration of the Korean institute of civil engineering and building technology (KICT) and Korea Environment Industry \& Technology Institute (KEITI) through Industrial Facilities \& Infrastructure Research Program, funded by Korea Ministry of Environment(MOE) (1485016257), Republic of Korea. M. M. Damtie and R. H. Hailemariam also acknowledge admin support from the university of science \& technology (UST), Republic of Korea and University of Technology Sydney, Australia.

This article was presented at the 2019 International Desalination Workshop (IDW2019) held on 28-30 August 2019, Jeju, Korea.

\section{Author Contributions}

J.-S.C. (Dr.), H.K.S. (Dr.), and L.D.T. (Dr.) initiated and supervised the work. M.M.D. (Ph.D student) conducted all the necessary experiments in this project. F.V. (Ph.D. student), M.Y. (Dr.), and T.B. (Dr.) supported all the experiments. R.H.H. and K.-D.P.' assisted the data analysis, manuscript structuring and writeup.

\section{References}

1. White PJ, Brown PH. Plant nutrition for sustainable development and global health. Ann. Bot. 2010;105:1073-1080.

2. Ye Y, Ngo HH, Guo W, et al. A critical review on ammonium recovery from wastewater for sustainable wastewater management. Bioresour. Technol. 2018;268:749-758.

3. Ahn YT, Hwang YH, Shin HS. Application of PTFE membrane for ammonia removal in a membrane contactor. Water Sci. Technol. 2011; 63:2944-2948.

4. Udert KM, Wächter M. Complete nutrient recovery from source-separated urine by nitrification and distillation. Water Res. 2012; 46:453-464.

5. Kabdaşli I, Tünay O, Işlek C, Erdinç E, Hüskalar S, Tatli MB. Nitrogen recovery by urea hydrolysis and struvite precipitation from anthropogenic urine. Water Sci. Technol. 2006;53:305-312.

6. Udert KM, Larsen TA, Biebow M, Gujer W. Urea hydrolysis and precipitation dynamics in a urine-collecting system. Water Res. 2003; 37:2571-2582.

7. Başakçilardan-Kabakçi S, Ipekoğlu AN, Talinli I. Recovery of Ammonia from Human Urine by Stripping and Absorption. Environ. Eng. Sci. 2007;24:615-624.

8. Bonmati A, Flotats X. Air stripping of ammonia from pig slurry: characterisation and feasibility as a pre- or post-treatment to mesophilic anaerobic digestion. Waste Manage. 2003;23:261-272.

9. Pradhan SK, Mikola A, Vahala R. Nitrogen and Phosphorus Harvesting from Human Urine Using a Stripping, Absorption, and Precipitation Process. Environ. Sci. Technol. 2017;51:5165-5171.

10. Tao W, Ukwuani AT. Coupling thermal stripping and acid absorption for ammonia recovery from dairy manure: Ammonia volatilization kinetics and effects of temperature, $\mathrm{pH}$ and dissolved solids content. Chem. Eng. J. 2015;280:188-196.

11. Masse L, Massé DI, Pellerin Y, Dubreuil J. Osmotic pressure and substrate resistance during the concentration of manure nutrients by reverse osmosis membranes. J. Membr. Sci. 2010;348:28-33.

12. Tarpeh WA, Barazesh JM, Cath TY, Nelson KL. Electrochemical Stripping to Recover Nitrogen from Source-Separated Urine. Environ. Sci. Technol. 2018;52:1453-1460.

13. Tarpeh WA, Udert KM, Nelson KL. Comparing Ion Exchange Adsorbents for Nitrogen Recovery from Source-Separated Urine. Environ. Sci. Technol. 2017;51:2373-2381.

14. Nagy J, Kaljunen J, Toth AJ. Nitrogen recovery from wastewater and human urine with hydrophobic gas separation membrane: experiments and modelling. Chem. Pap. 2019;73:1903-1915.

15. Manna AK, Sen M, Martin AR, Pal P. Removal of arsenic from contaminated groundwater by solar-driven membrane 
distillation. Environ. Pollut. 2010;158:805-811.

16. Zolotarev PP, Ugrozov VV, Volkina IB, Nikulin VM. Treatment of waste water for removing heavy metals by membrane distillation. J. Hazard. Mat. 1994;37:77-82.

17. Damtie MM, Hailemariam RH, Woo YC, Park K-D, Choi J-S. Membrane-based technologies for zero liquid discharge and fluoride removal from industrial wastewater. Chemosphere 2019;236:124-288.

18. Damtie MM, Woo YC, Kim B, et al. Analysis of mass transfer behavior in membrane distillation: Mathematical modeling under various conditions. Chemosphere 2019;236:124-289.

19. Damtie MM, Kim B, Woo YC, Choi JS. Membrane distillation for industrial wastewater treatment: Studying the effects of membrane parameters on the wetting performance. Chemosphere 2018;206:793-801.

20. Damtie MM, Choi J-S. Modeling and application of direct contact membrane distillation for fluoride removal from aqueous solutions. Desalin. Water Treat. 2017;97:23-40.

21. Abdelkader S, Boubakri A, Geissen SU, Bousselmi L. Direct contact membrane distillation applied to saline wastewater: parameter optimization. Water Sci. Technol. 2018;77:2823-2833.

22. Daguerre-Martini S, Vanotti MB, Rodriguez-Pastor M, Rosal A, Moral R. Nitrogen recovery from wastewater using gas-permeable membranes: Impact of inorganic carbon content and natural organic matter. Water Res. 2018;137:201-210.

23. Darestani M, Haigh V, Couperthwaite SJ, Millar GJ, Nghiem
LD. Hollow fibre membrane contactors for ammonia recovery: Current status and future developments. J. Environ. Chem. Eng. 2017;5:1349-1359.

24. Lai C-L, Chen S, Liou R-M. Removing aqueous ammonia by membrane contactor process. Desalin. Water Treat. 2013;51: 5307-5310.

25. Nagaraj N, Patil G, Babu BR, Hebbar UH, Raghavarao KSMS, Nene S. Mass transfer in osmotic membrane distillation. J. Membr. Sci. 2006;268:48-56.

26. Zhang J, She Q, Chang VWC, Tang CY, Webster RD. Mining Nutrients (N, K, P) from Urban Source-Separated Urine by Forward Osmosis Dewatering. Environ. Sci. Technol. 2014;48: 3386-3394.

27. Zhu Z, Hao Z, Shen Z, Chen J. Modified modeling of the effect of $\mathrm{pH}$ and viscosity on the mass transfer in hydrophobic hollow fiber membrane contactors. J. Membr. Sci. 2005;250:269-276.

28. Ashrafizadeh SN, Khorasani Z. Ammonia removal from aqueous solutions using hollow-fiber membrane contactors. Chem. Eng. J. 2010;162:242-249.

29. Sutrasno K, Galih Mery D, Cahya Tri R. Effects of Absorbents on Ammonia Removal from Wastewater Through Hollow Fiber Membrane Contactor. Int. J. Environ. Sci. Technol. 2015;8: 225-231.

30. Shao J, Fang X, He Y, Jin Q. Emergency membrane contactor based absorption system for ammonia leaks in water treatment plants. J. Environ. Sci. (China) 2008;20:1189-1194. 